\title{
Article \\ Quantitative Characterization of Geotrichum candidum Growth in Milk
}

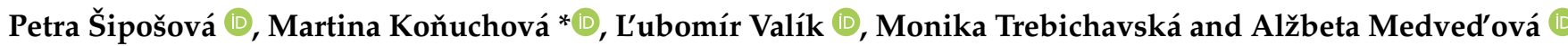 \\ Department of Nutrition and Food Quality Assessment, Institute of Food Sciences and Nutrition, \\ Faculty of Chemical and Food Technology, Slovak University of Technology in Bratislava, Radlinského 9, \\ SK-812 37 Bratislava, Slovakia; petra.siposova@stuba.sk (P.Š.); lubomir.valik@stuba.sk (L'.V.); \\ monika.trebichavska@stuba.sk (M.T.); alzbeta.medvedova@stuba.sk (A.M.) \\ * Correspondence: martina.konuchova@stuba.sk
}

check for updates

Citation: Šipošová, P.;

Koňuchová, M.; Valík, L'.;

Trebichavská, M.; Medved'ová, A Quantitative Characterization of Geotrichum candidum Growth in Milk. Appl. Sci. 2021, 11, 4619. https:// doi.org/10.3390/app11104619

Academic Editor: Teresa Cirillo

Received: 21 April 2021

Accepted: 18 May 2021

Published: 18 May 2021

Publisher's Note: MDPI stays neutral with regard to jurisdictional claims in published maps and institutional affiliations.

Copyright: (c) 2021 by the authors. Licensee MDPI, Basel, Switzerland. This article is an open access article distributed under the terms and conditions of the Creative Commons Attribution (CC BY) license (https:// creativecommons.org/licenses/by/ $4.0 /)$.

\begin{abstract}
The study of microbial growth in relation to food environments provides essential knowledge for food quality control. With respect to its significance in the dairy industry, the growth of Geotrichum candidum isolate $\mathrm{J}$ in milk without and with $1 \% \mathrm{NaCl}$ was investigated under isothermal conditions ranging from 6 to $37^{\circ} \mathrm{C}$. The mechanistic model by Baranyi and Roberts was used to fit the fungal counts over time and to estimate the growth parameters of the isolate. The effect of temperature on the growth of G. candidum in milk was modelled with the cardinal models, and the cardinal temperatures were calculated as $T_{\min }=-3.8-0.0{ }^{\circ} \mathrm{C}, T_{\text {opt }}=28.0-34.6{ }^{\circ} \mathrm{C}$, and $T_{\max }=35.2-37.2^{\circ} \mathrm{C}$. The growth of G. candidum $\mathrm{J}$ was slightly faster in milk with $1 \% \mathrm{NaCl}$ and in temperature regions under $21^{\circ} \mathrm{C}$. However, in a temperature range that was close to the optimum, its growth was slightly inhibited by the lowered water activity level. The present study provides useful cultivation data for understanding the behaviour of G. candidum in milk and can serve as an effective tool for assessing the risk of fungal spoilage, predicting the shelf life of dairy products, or assessing the optimal conditions for its growth in relation to the operational parameters in dairy practices.
\end{abstract}

Keywords: Geotrichum candidum; predictive microbiology; cardinal models

\section{Introduction}

The close connection of G. candidum with milk and dairy products was reported as early as 1850, when Fresenius isolated and named this microorganism Oidium lactis. G. candidum has undergone extensive taxonomic revision since the genus Geotrichum was firstly erected by Link in 1809, and it is still evolving [1-5]. Nevertheless, the classification of this species as a filamentous yeast-like fungus is generally accepted [3,4]. G. candidum is currently known as a ubiquitous microscopic fungus with a worldwide distribution that is commonly found in soil, water, air, silage, grass, plants, fruits, vegetables, raw milk, and dairy products. It is also a commensal organism of the human and animal digestive tract [2-7].

According to the International Dairy Federation (IDF) and the European Food and Feed Cultures Association (EFFCA), G. candidum is included in an authoritative list of microorganisms with a documented history of safe use in fermented foods [8]. The application of this fungus in the manufacturing of fermented dairy products resulted from its common presence in raw milk, regardless of animal origin (cow, goat, sheep, camel, or buffalo) $[2,9,10]$. However, the concentration of $G$. candidum in raw milk is generally low $\left(<10^{2}\right.$ colony-forming units $\left.(\mathrm{CFU}) \cdot \mathrm{mL}^{-1}\right)$. In dairy practice, $\mathrm{G}$. candidum is used as an adjunct culture in the production of regional fermented milks (e.g., Viili, Kefir) and a wide range of ripened cheeses, including soft mould-ripened cheeses, soft and semi-hard smear-ripened cheeses, and acid-coagulated cheeses [2,5,11-14]. The growth of this milk fungus can be observed on the cheese's surface around the third day of ripening, and it can reach a density of up to $10^{5}-10^{7}$ TFU (thallus-forming units) per gram of cheese $[4,15]$. 
G. candidum contributes to the cheese's flavour, aroma, and appearance. Characteristic organoleptic attributes resulting from the presence of G. candidum in dairy products include mildly cheesy, mouldy, sweaty, putrid, acidic, yeasty, musty, fermented, cidery, and fruity flavours and a velvety, felted, or lightly fluffy appearance, with an overall good hedonic perception [2,16]. Additionally, this species may contribute to the microbial safety of dairy products. The antimicrobial potential of G. candidum against undesirable and pathogenic microorganisms, including Listeria monocytogenes, Staphylococcus aureus, Bacillus cereus, Escherichia coli, Aspergillus ochraceus, and Mucor species has been described [2,4,17,18].

However, another aspect of the relevance of G. candidum in the food industry must also be considered. G. candidum is known as a spoilage organism in certain dairy products, e.g., butter, cream, and cottage cheese. Uncontrolled growth of this species may lead to the development of off-flavours and cheese defects, such as a slippery rind or toad skin defects $[5,7]$. G. candidum has also been noticed as a machinery mould that can readily grow on all surfaces contacted by food products, and thus, its growth may cause severe economic losses for food producers [5,19].

With respect to its relevance in the food industry, the biochemical activity of G. candidum has already been deeply investigated [5,7,20-22]. However, there are only a few studies regarding the quantitative approach to the growth dynamics of G. candidum. Detailed knowledge of microbial responses to the environmental conditions enables a better control under microbial behaviour, which is an important part of food quality management. Microbial ecology and growth parameters can be quantitatively defined with the use of predictive microbiological tools. The concept of predictive microbiology is based on mathematical models, that enable an objective evaluation of microbial behaviour (growth, survival, inactivation, etc.) in a dependence on environmental factors [23,24], since the responses to a changing environment are reproducible [25]. Therefore, the aim of this study was to characterize the growth of G. candidum in milk quantitatively in relation to salt addition and changing temperature, and so the growth of G. candidum as a part of adjunct or natural cheese microbiota can be predicted. The data obtained here can be further used for microbial growth control and product quality optimization in dairy practices.

\section{Materials and Methods}

\subsection{Fungal Isolate and Culture Preparation}

An isolate J of G. candidum was used for all experiments in the present study. The monitored isolate, which was selected from the collection of the Institute of Food Science and Nutrition (Slovak University of Technology in Bratislava, Slovak Republic), originated from the artisanal Slovak "Bryndza" cheese (Turčianske Teplice, Slovak Republic). The identity of the isolate was confirmed based on morphological, biochemical, and molecular characteristics in accordance with Samson et al. [26], De Hoog and Smith [27], and Groenewald et al. [28]. The isolate was stored under refrigeration $\left(5 \pm 0.5^{\circ} \mathrm{C}\right)$ on Plate Count Skim Milk Agar (SMA; Merck, Darmstadt, Germany) slant, and it was sub-cultured monthly.

\subsection{Inoculum Preparation and Experimental Design}

G. candidum was cultivated for $72 \mathrm{~h}$ on the upper layer of a horizontal solidified SMA agar in a tube at $25 \pm 0.5^{\circ} \mathrm{C}$. Parallel cultivated isolates were then mixed with $10 \mathrm{~mL}$ of sterile peptone-saline solution and released through soft rubbing of the agar's surface with a sterile cell scraper. Immediately after the preparation, an appropriate decimal dilution of this culture was used to inoculate $300 \mathrm{~mL}$ of pre-tempered ultra-high temperature processed (UHT) milk with an initial level, which ranged approximately from 1.5 to 2.0 CFU. $\mathrm{mL}^{-1}$.

The effect of $\mathrm{NaCl}$ addition ( 0 and $1 \%, w / v)$ on the kinetic growth behaviour of G. candidum isolate J was evaluated in UHT milk (1.5\% fat content; Rajo Inc., Bratislava, Slovak Republic) at temperatures of $6,8,12,15,18,21,25,30,34$, and $37 \pm 0.5^{\circ} \mathrm{C}$ under static aerobic conditions. The aforementioned temperatures were selected in an attempt to fully cover the growth region of the species to the greatest possible extent. Considering the 
salt sensitivity of G. candidum contrary to the majority of other dairy yeasts, only addition of $1 \% \mathrm{NaCl}$ was evaluated. To obtain well-fitting data, three replicates were performed per experiment.

Actual viable counts of the isolate were determined at predefined time intervals based on the incubation temperature by plating on DRBC agar (Biokar Diagnostics, Beauvais, France) according to EN ISO 21527-1 [29] with aerobic incubation at $25 \pm 0.5^{\circ} \mathrm{C}$ for 5 days. The $\mathrm{pH}$ of the milk samples was analysed using a calibrated WTW $720 \mathrm{pH}$-meter (Inolab, Weilheim, Germany) equipped with a Sen Tix 81 glass electrode (WTW GmbH, Weilheim, Germany) with the same time interval as the microbiological determination.

\subsection{Growth Curve Fitting}

\subsubsection{Primary Modelling}

The model proposed by Baranyi and Roberts [30] was fitted to the data of G. candidum growth in milk to estimate the kinetic parameters of the growth. The microbial counts obtained from the cultivation experiments were transformed into units of $\log _{10} \mathrm{CFU} \cdot \mathrm{mL}^{-1}$ prior to model fitting. The Microsoft Excel 365 (Microsoft Corp., Redmond, WA, USA) add-in DMFit (Version 3.5, ComBase, University of Tasmania, Australia, and the USDA Agricultural Research Service, Washington, DC, USA) was employed to fit the log count vs. time data and extract growth parameters, such as the growth rate $(\mathrm{Gr})$ or lag phase duration $(\lambda)$. The maximum specific growth rate $\left(\mu_{\max }\right)$ was subsequently calculated as:

$$
\mu_{\max }=\ln 10 . G r
$$

\subsubsection{Secondary Modelling}

The cardinal model (CM) by Rosso et al. [31] was used to fit the reciprocal lag time $1 / \lambda\left(\mathrm{h}^{-1}\right)$ as well as the maximum specific growth rate $\mu_{\max }\left(\mathrm{h}^{-1}\right)$ against the temperature $(T)$ :

$$
\begin{aligned}
& \mu_{\max }=\mu_{\mathrm{opt}} \frac{\left(T-T_{\mathrm{max}}\right)\left(T-T_{\min }\right)^{2}}{\left(T_{\mathrm{opt}}-T_{\min }\right)\left[\left(T_{\mathrm{opt}}-T_{\min }\right)\left(T-T_{\mathrm{opt}}\right)-\left(T_{\mathrm{opt}}-T_{\max }\right)\left(T_{\mathrm{opt}}+T_{\min }-2 T\right)\right]} \\
& 1 / \lambda=1 / \lambda_{\mathrm{opt}} \frac{\left(T-T_{\mathrm{max}}\right)\left(T-T_{\min }\right)^{2}}{\left(T_{\mathrm{opt}}-T_{\min }\right)\left[\left(T_{\mathrm{opt}}-T_{\min }\right)\left(T-T_{\mathrm{opt}}\right)-\left(T_{\mathrm{opt}}-T_{\max }\right)\left(T_{\mathrm{opt}}+T_{\min }-2 T\right)\right]}
\end{aligned}
$$

This secondary predictive model includes only parameters with direct biological meaning, such as $\mu_{\mathrm{opt}}$ (maximum specific growth rate at the temperature optimum), $T_{\text {min }}$ (theoretical minimum temperature), $T_{\text {opt }}$ (optimal temperature for the growth of the studied microorganism), and $T_{\max }$ (maximum temperature above which microbial growth is not likely).

\subsubsection{Statistical Analysis and Validation}

The data obtained from the primary modelling were treated with an analysis of variance (ANOVA) to assess if the effects of temperature or salt addition on the kinetic growth of G. candidum were significant. A statistical analysis with a least significant difference of 95\% was carried out using Microsoft Excel 365.

To evaluate the accuracy of the primary and secondary models' fit, the coefficient of determination $\left(R^{2}\right)$ and root mean square error (RMSE) were calculated:

$$
\begin{gathered}
R^{2}=1-\frac{\sum_{i=1}^{n}\left(y_{i}^{\text {exp }}-y_{i}^{\text {pred }}\right)^{2}}{\sum_{i=1}^{n}\left(y_{i}^{\text {exp }}-\bar{y}_{i}^{\text {exp }}\right)^{2}} \\
R M S E=\sqrt{\frac{\sum_{i=1}^{n}\left(y_{i}^{\text {exp }}-y_{i}^{\text {pred }}\right)^{2}}{n-p}}
\end{gathered}
$$


where $y_{i}^{\text {exp }}$ and $y_{i}^{\text {pred }}$ are the experimental and predicted growth data, respectively; $n$ is the number of experimental observations; and $p$ is the number of model parameters [32-34].

Accuracy $\left(A_{\mathrm{f}}\right)$ and bias $\left(B_{\mathrm{f}}\right)$ factors, as introduced by Baranyi et al. [35], were used for internal validation of the secondary models according to:

$$
\begin{aligned}
& A_{f}=10 \sqrt{\frac{\sum_{i=1}^{n}\left(\log y_{i}^{\text {pred }}-\log y_{i}^{\text {exp }}\right)^{2}}{n}} \\
& B_{f}=10^{\frac{\sum_{i=1}^{n}\left(\log y_{i}^{\text {pred }}-\log y_{i}^{\text {exp }}\right)^{2}}{n}}
\end{aligned}
$$

\section{Results}

\subsection{Primary Modelling of G. candidum Growth in Milk}

In this study, we used the primary mechanistic model proposed by Baranyi and Roberts [30], which is the most appropriate in comparison with other primary models that are based on statistical indices [34]. Although it was primarily constructed for bacterial growth predictions, it has also been frequently used to describe fungal growth [12,36-40].

The average initial counts $\left(N_{0} \pm\right.$ standard deviation) of G. candidum $\mathrm{J}$ in milk were $1.55 \pm 0.18 \log \mathrm{CFU} \cdot \mathrm{mL}^{-1}$ (coefficient of variation: $\mathrm{CV}=11.6 \%$ ) in all experiments without $\mathrm{NaCl}$ addition $(n=30)$ and $1.88 \pm 0.19 \log \mathrm{CFU} \cdot \mathrm{mL}^{-1}(\mathrm{CV}=10.3 \%)$ in milk with $1 \% \mathrm{NaCl}$. This density is in accordance with the inherent presence of G. candidum in raw milk $[2,13]$. The growth curves of the isolate (Figure 1) in milk were characterised by a typical sigmoidal shape, with an exception at $37^{\circ} \mathrm{C}$, when the survival and subsequent decline of G. candidum counts were observed. However, during its cultivation in milk with $1 \% \mathrm{NaCl}$ and in a suboptimal temperature range, we repeatedly observed a slight decline in G. candidum counts before the exponential growth phase. Since the lag phase represents the transient period of non-replication during which microorganisms adjust to the new environment, a decrease in the number of viable cells may also occur before the exponential phase [41]. Therefore, for the most appropriate fitting of the growth data by the modelling program (DMFit), we transformed the decreased counts of G. candidum into the average of the counts occurring in the lag phase (Figure 2).

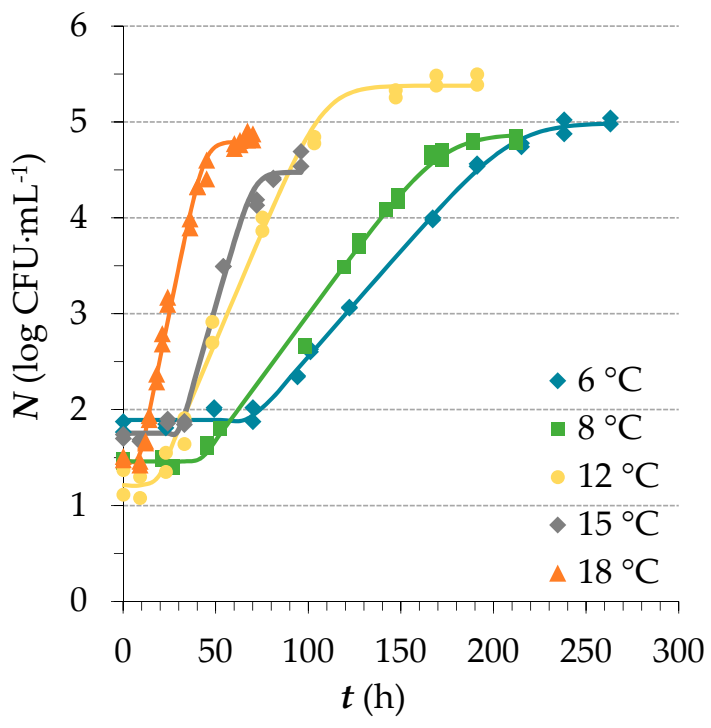

(a)

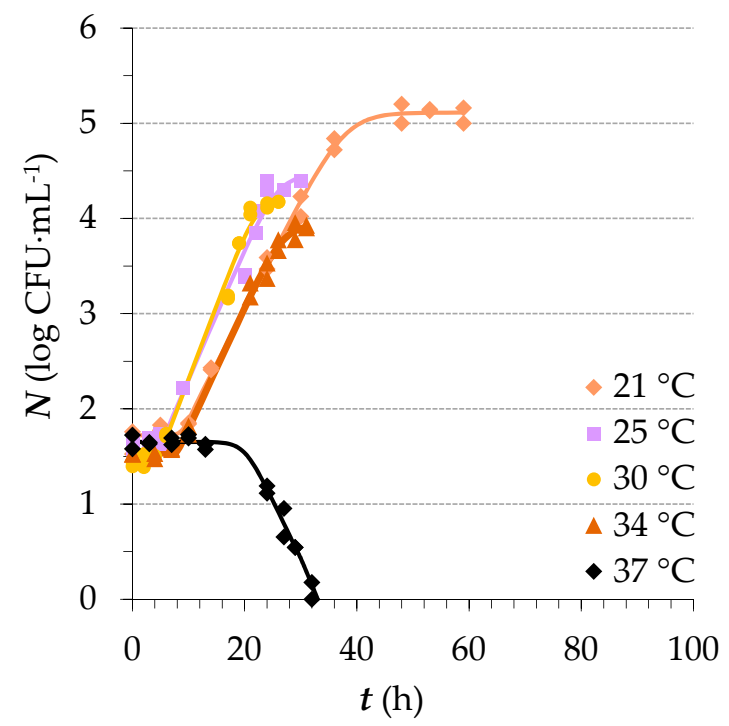

(b)

Figure 1. Growth curves of G. candidum isolate J in ultra-high temperature processed (UHT) milk without $\mathrm{NaCl}$ in the temperature ranges of $6-18{ }^{\circ} \mathrm{C}(\mathbf{a})$ and $21-37^{\circ} \mathrm{C}(\mathbf{b})$. The points represent the observed values of counts of G. candidum. The continuous lines represent fitted growth curve according to the DMFit modelling program. 


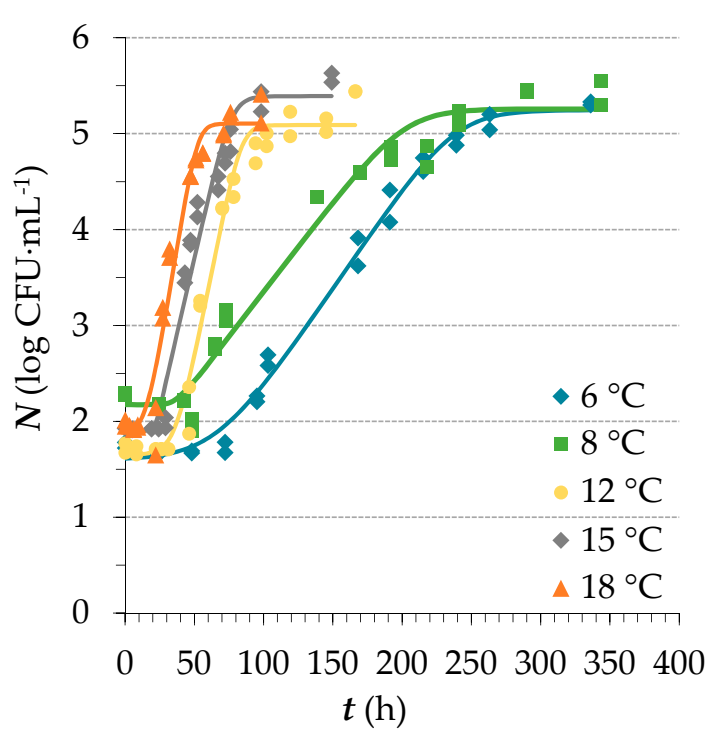

(a)

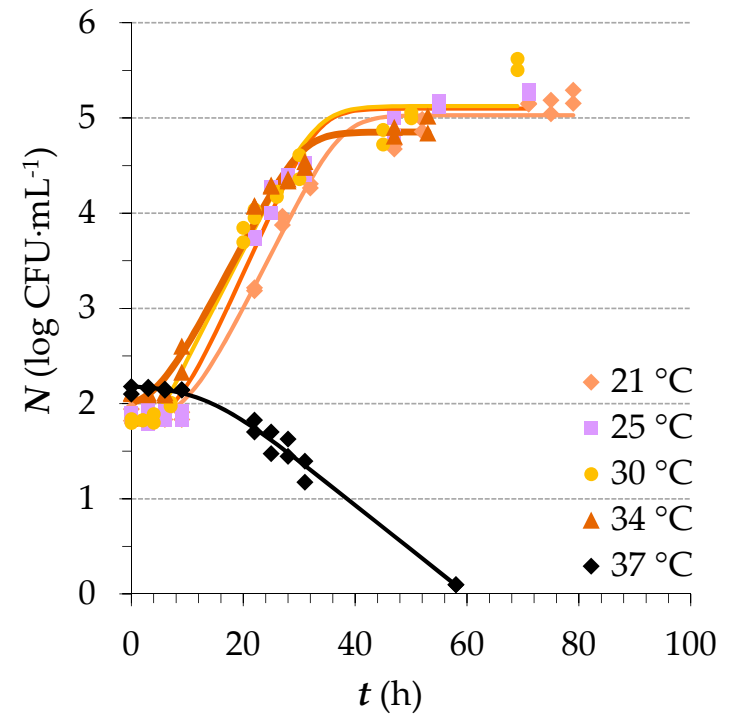

(b)

Figure 2. Growth curves of $\mathrm{G}$. candidum isolate $\mathrm{J}$ in UHT milk with $1 \% \mathrm{NaCl}$ in the temperature ranges of $6-18^{\circ} \mathrm{C}(\mathbf{a})$ and $21-37^{\circ} \mathrm{C}(\mathbf{b})$. The points represent the observed values of counts of $G$. candidum. The continuous lines represent fitted growth curve according to DMFit modelling program.

The growth parameters from the primary modelling are summarized in Table 1. The longest lag phase durations of G. candidum growth in milk without and with $1 \% \mathrm{NaCl}$, respectively, were observed at the minimum cultivation temperature used in our study $\left(6^{\circ} \mathrm{C}\right)$ and lasted for almost 3 days. Despite this low incubation temperature, G. candidum was able to grow and increased the initial counts by more than three logs within 9 days. Although this cooling temperature is used in practice to minimize microbial growth and to extend the shelf life of non-sterile dairy products [10], it is obvious from our results that the growth of G. candidum is enabled under these circumstances, and it may lead to spoilage of dairy products. Organoleptic defects in certain dairy products (e.g., cottage cheese and cream) are obvious when the fungal population is at least $10^{4}-10^{5} \mathrm{CFU} \mathrm{g}{ }^{-1}$ [42]. Based on our results, G. candidum could reach that density in 7 or 8 days at $6{ }^{\circ} \mathrm{C}$ in milk without or with $1 \% \mathrm{NaCl}$, respectively. These data should be considered in dairy practices for controlling food quality and effective shelf-life management, including for predictions within consumers' households.

Further increases in the cultivation temperature led to significantly $(p<0.05)$ more intense growth of the isolate in milk. The highest growth rate and the shortest duration of the lag phase were observed at the cultivation temperature of $30^{\circ} \mathrm{C}$. Detailed knowledge of the lag phase duration and the rate of G. candidum growth in milk at $30^{\circ} \mathrm{C}$, that is, the temperature of milk coagulation in cheese practices [43], may be helpful in the manufacturing of cheeses with the intentional addition of G. candidum culture or in cheese production with raw milk. On the other hand, the effect of temperature on G. candidum growth in milk with added salt was less obvious as it was in milk without added salt. There were no significant $(p<0.05)$ differences in growth rate of the isolate at 6 and $8{ }^{\circ} \mathrm{C}$ or at 12 and $15^{\circ} \mathrm{C}$. However, the specific growth rate of the isolate significantly $(p<0.05)$ increased with the increase in cultivation temperature from 15 to $25^{\circ} \mathrm{C}$. 
Table 1. Growth parameters of G. candidum J in UHT milk depending on $\mathrm{NaCl}$ addition.

\begin{tabular}{|c|c|c|c|c|}
\hline $\begin{array}{c}\mathrm{T} \\
\left({ }^{\circ} \mathrm{C}\right)\end{array}$ & $\begin{array}{c}\mathrm{NaCl} \\
(\%)\end{array}$ & $\begin{array}{l}\mu_{\max } \\
\left(\mathbf{h}^{-1}\right)\end{array}$ & $\begin{array}{c}\lambda \\
\text { (h) }\end{array}$ & $\begin{array}{c}N_{\max } \\
\left(\log \mathrm{CFU} \cdot \mathrm{mL}^{-1}\right)\end{array}$ \\
\hline \multirow[b]{2}{*}{6} & 0 & $0.051 \pm 0.000^{a, x}$ & $70.0 \pm 1.46^{\mathrm{a}, \mathrm{x}}$ & $5.01 \pm 0.05^{\mathrm{a}, \mathrm{x}}$ \\
\hline & 1 & $0.049 \pm 0.003^{\mathrm{m}, \mathrm{x}}$ & $66.2 \pm 1.06^{\mathrm{m}, \mathrm{y}}$ & $5.32 \pm 0.02^{a, y}$ \\
\hline \multirow{2}{*}{8} & 0 & $0.060 \pm 0.000^{b, x}$ & $41.5 \pm 0.13^{b, x}$ & $4.87 \pm 0.12^{a, x}$ \\
\hline & 1 & $0.043 \pm 0.004^{\mathrm{m}, \mathrm{y}}$ & $37.2 \pm 2.97^{\mathrm{n}, \mathrm{x}}$ & $5.43 \pm 0.18^{a, y}$ \\
\hline \multirow{2}{*}{12} & 0 & $0.106 \pm 0.000^{c, x}$ & $17.3 \pm 1.65^{c, x}$ & $5.44 \pm 0.08^{b, x}$ \\
\hline & 1 & $0.166 \pm 0.017^{\mathrm{n}, \mathrm{y}}$ & $36.1 \pm 3.79^{n, y}$ & $5.45 \pm 0.01^{\mathrm{a}, \mathrm{x}}$ \\
\hline \multirow{2}{*}{15} & 0 & $0.157 \pm 0.008^{\mathrm{d}, \mathrm{x}}$ & $30.5 \pm 0.59^{d, x}$ & $4.61 \pm 0.11^{\mathrm{c}, \mathrm{x}}$ \\
\hline & 1 & $0.145 \pm 0.007^{\mathrm{n}, \mathrm{x}}$ & $21.4 \pm 0.51^{\mathrm{o}, \mathrm{y}}$ & $5.59 \pm 0.06^{b, y}$ \\
\hline \multirow{2}{*}{18} & 0 & $0.219 \pm 0.002^{\mathrm{e}, \mathrm{x}}$ & $8.8 \pm 0.03^{e, x}$ & $4.84 \pm 0.04^{\mathrm{d}, \mathrm{x}}$ \\
\hline & 1 & $0.199 \pm 0.021^{\mathrm{o}, \mathrm{x}}$ & $15.1 \pm 2.33 p, y$ & $5.26 \pm 0.21^{c, y}$ \\
\hline \multirow{2}{*}{21} & 0 & $0.266 \pm 0.011^{f, x}$ & $8.5 \pm 0.78^{e, x}$ & $4.93 \pm 0.07^{\mathrm{d}, \mathrm{x}}$ \\
\hline & 1 & $0.267 \pm 0.005 \mathrm{p}, \mathrm{x}$ & $9.7 \pm 0.32 \mathrm{q}, \mathrm{x}$ & $5.23 \pm 0.09^{c, y}$ \\
\hline \multirow{2}{*}{25} & 0 & $0.315 \pm 0.004 \mathrm{~g}, \mathrm{x}$ & $5.2 \pm 0.38^{f, x}$ & $4.40 \pm 0.00^{\mathrm{e}, \mathrm{x}}$ \\
\hline & 1 & $0.300 \pm 0.008 \mathrm{q}, \mathrm{y}$ & $7.7 \pm 0.20^{\mathrm{r}, \mathrm{y}}$ & $5.28 \pm 0.03^{c, y}$ \\
\hline \multirow{2}{*}{30} & 0 & $0.359 \pm 0.005^{h, x}$ & $4.6 \pm 0.57^{\mathrm{f}, \mathrm{x}}$ & $4.18 \pm 0.00^{\mathrm{f}, \mathrm{x}}$ \\
\hline & 1 & $0.265 \pm 0.008^{\mathrm{r}, \mathrm{y}}$ & $4.3 \pm 0.18^{\mathrm{s}, \mathrm{x}}$ & $5.57 \pm 0.08^{\mathrm{d}, \mathrm{y}}$ \\
\hline \multirow{2}{*}{34} & 0 & $0.293 \pm 0.005^{\mathrm{i}, \mathrm{x}}$ & $8.0 \pm 1.40^{g, x}$ & $3.92 \pm 0.02^{g, x}$ \\
\hline & 1 & $0.254 \pm 0.019^{\mathrm{r}, \mathrm{y}}$ & $4.8 \pm 0.93^{\mathrm{s}, \mathrm{y}}$ & $4.94 \pm 0.12^{\mathrm{e}, \mathrm{y}}$ \\
\hline \multirow[b]{2}{*}{37} & 0 & $-0.285 \pm 0.017 \mathrm{j}, \mathrm{x}$ & $20.1 \pm 1.08^{h, x}$ & - \\
\hline & 1 & $-0.108 \pm 0.007^{\mathrm{s}, \mathrm{y}}$ & $13.3 \pm 3.89^{\mathrm{t}, \mathrm{y}}$ & - \\
\hline
\end{tabular}

T-incubation temperature; $\mu_{\max }$-maximum specific growth rate; $\lambda$-lag phase duration; $N_{0}$-initial counts $N_{\max }$-maximum counts in the stationary phase. ${ }^{a-j}$ - different superscript letters among data observed in milk with $0 \% \mathrm{NaCl}$ indicate statistical significance with increasing temperature $(p<0.05) ;{ }^{\mathrm{m}-\mathrm{t}}$ - different superscript letters between data observed in milk with $1 \% \mathrm{NaCl}$ indicate statistical significance with increasing temperature $(p<0.05) ; \mathrm{x}, \mathrm{y}$ - different superscript letters indicate statistical significance between data in milk with $0 \% \mathrm{NaCl}$ and $1 \% \mathrm{NaCl}(p<0.05)$.

Higher temperatures than $30^{\circ} \mathrm{C}$ caused a decline in the growth rate in both casesG. candidum growth in milk without and with $1 \% \mathrm{NaCl}$. As already mentioned, at the cultivation temperature of $37^{\circ} \mathrm{C}$, the G. candidum log counts continuously decreased after lag phase durations that were shorter than $24 \mathrm{~h}$, regardless of the salt content in the milk. This result is in accordance with that of Koňuchová and Valík [44], who did not observe any growth of G. candidum isolate I on the surface of skim milk agar at $37^{\circ} \mathrm{C}$. The studies of other cheese-related yeasts demonstrated similar patterns of response to temperature $[16,45,46]$. In addition, Agarbati et al. [47] reported Debaryomyces hansenii MM6 1194 and PCF1 1148 or Candida zeylanoides 7 as unable to grow at $37^{\circ} \mathrm{C}$. Although we observed significantly $(p<0.05)$ slower inactivation of G. candidum cells in milk with $1 \% \mathrm{NaCl}$ in contrast to the rate of devitalisation of the isolate in milk without salt, more experiments would be needed to understand the protective effect of salt against the higher temperature in this specific case. However, the effect of decreasing water activity, which increases the microbial tolerance and even the resistance to higher temperatures, is generally known [48].

In contrast to the lag phase duration and growth rate of G. candidum J, counts of the isolate in the stationary phase were almost equal in all experiments (excluding the growth curves at $37^{\circ} \mathrm{C}$ ) at the level of $10^{4}-10^{5} \log \mathrm{CFU} \cdot \mathrm{mL}^{-1}$. In addition, the $\mathrm{pH}$ of the milk growth medium was stable during all of the experiments performed, with an average initial value of $6.54 \pm 0.05(C V=0.8 \%, n=10)$ and average final value of $6.53 \pm 0.08$ $(\mathrm{CV}=1.2 \%)$. Similarly, the $\mathrm{pH}$ of milk with $1 \% \mathrm{NaCl}$ had the average initial value of $6.50 \pm 0.02(C V=0.3 \%)$ and final value of $6.52 \pm 0.04(C V=0.6 \%)$. This may result from the fact that G. candidum is unable to ferment lactose [2,7]. Although the optimal $\mathrm{pH}$ for $G$. candidum growth was reported to be in the range of 5.5-6.0 [4,5,49], according to Šípková 
et al. [50], the $\mathrm{pH}$ range of 5.5-6.6 has no significant impact on the growth of G. candidum in milk.

\subsection{Secondary Modelling of G. candidum Growth in Milk}

In general, temperature is the most significant external environmental factor that affects microbial growth. That is why the secondary modelling in terms of the quantitative evaluation of temperature's effect on G. candidum growth was performed.

As shown in Figure 3, the duration of lag phase decreased with increasing temperature and slightly increased in the area beyond the optimum towards the maximum values of the temperature. The qualitative growth study of Koňuchová and Valík [44] demonstrated a similar pattern of surface growth responses to temperature in the G. candidum lag phase duration.

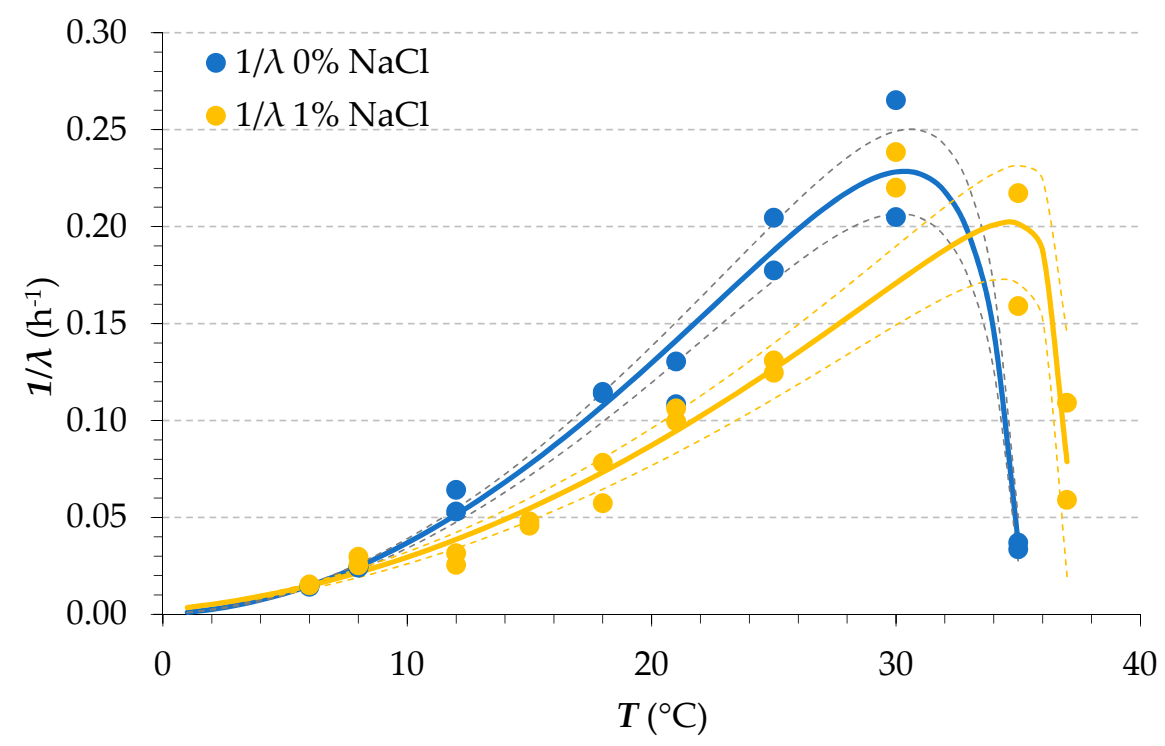

Figure 3. Plots of the reciprocal lag phase duration of the G. candidum isolate in relation to the temperature $\left(6-37^{\circ} \mathrm{C}\right.$ ) in milk (blue line) and milk with $1 \% \mathrm{NaCl}$ (yellow line) according to the cardinal model (CM, solid line). The symbols indicate the experimental values of $1 / \lambda$ estimated from the primary model at each incubation temperature. Solid lines represent the fitted estimates according to the model. Dashed lines represent the $95 \%$ confidence intervals.

It was also obvious that the $\mathrm{CM}$ line representing the dependence of $1 / \lambda$ on temperature with $1 \% \mathrm{NaCl}$ moved down to lower values of $1 / \lambda$ and toward a higher temperature range. Specifically, this means that the lag phase durations were prolonged, the differences between $1 / \lambda$ values increased gradually with the temperature, and the predicted $T_{\mathrm{opt}}$ and $T_{\max }$ were higher by 4.3 and $2.0^{\circ} \mathrm{C}$ (Table 2), respectively, as a result of the addition of salt in the milk. On the other hand, the cardinal temperatures that resulted from CM when applied to the specific growth rate of the isolate in milk with and without added salt were very close to each other. Similar cardinal temperatures $\left(T_{\min }=1.18{ }^{\circ} \mathrm{C}, T_{\mathrm{opt}}=28.9^{\circ} \mathrm{C}\right.$, $T_{\max }=37.3^{\circ} \mathrm{C}$ ) for $\mathrm{G}$. candidum growth in milk were also reported by Šípková et al. [50]. The optimal specific growth rate of the isolate slightly decreased in the milk medium with $1 \% \mathrm{NaCl}$ addition in contrast to its optimal growth rate in milk. These results indicate the slower growth of G. candidum at $1 \% \mathrm{NaCl}$, which is in accordance with the findings of Eliskases-Lechner et al. [7] and Uraz and Özer [51]. However, strain-dependent sensitivity of G. candidum on salt concentration should also generally be considered [2,4,44]. 
Table 2. Cardinal parameters of the growth of G. candidum $\mathrm{J}$ in milk depending on $\mathrm{NaCl}$ presence as a result of $C M$ applied to the specific growth rate $\left(\mathrm{CM}_{\mu}\right)$ and lag phase $\left(\mathrm{CM}_{1 / \lambda}\right)$.

\begin{tabular}{ccccc}
\hline & \multicolumn{2}{c}{$\mathbf{0} \% \mathbf{~ N a C l}$} & \multicolumn{2}{c}{$\mathbf{1 \% ~ N a C l}$} \\
\hline Model & $\mathbf{C M}_{\mathbf{1} / \boldsymbol{\lambda}}$ & $\mathbf{C M}_{\boldsymbol{\mu}}$ & $\mathbf{C M}_{\mathbf{1} / \boldsymbol{\lambda}}$ & $\mathbf{C M}_{\boldsymbol{\mu}}$ \\
\hline$T_{\min }\left({ }^{\circ} \mathrm{C}\right)$ & $-0.81 \pm 0.01$ & 0 (fixed) & $-3.75 \pm 0.05$ & 0 (fixed) \\
$T_{\text {opt }}\left({ }^{\circ} \mathrm{C}\right)$ & $30.32 \pm 0.27$ & $28.00 \pm 0.06$ & $34.63 \pm 0.44$ & $28.27 \pm 0.14$ \\
$T_{\max }\left({ }^{\circ} \mathrm{C}\right)$ & $35.21 \pm 0.03$ & $35.20 \pm 0.05$ & $37.17 \pm 0.12$ & $36.62 \pm 0.12$ \\
$1 / \lambda_{\text {opt }}\left(\mathrm{h}^{-1}\right)$ & $0.229 \pm 0.022$ & - & $0.202 \pm 0.029$ & - \\
$\mu_{\text {opt }}\left(\mathrm{h}^{-1}\right)$ & - & $0.358 \pm 0.008$ & - & $0.325 \pm 0.016$ \\
\hline
\end{tabular}

$T_{\min }$-minimum temperature (theoretical value); $T_{\mathrm{opt}}$-optimal temperature; $T_{\max }$-maximum temperature, $1 / \lambda_{\mathrm{opt}}$ - reciprocal lag phase duration at the optimal temperature; $\mu_{\mathrm{opt}}$-maximum specific growth rate at the optimal temperature; $\mathrm{CM}_{1 / \lambda}$-cardinal model applied to its lag phase data; $\mathrm{CM}_{\mu}$-cardinal model applied to its specific growth rate.

According to Eliskases-Lechner et al. [7], G. candidum species grow at temperatures ranging from 5 to $35^{\circ} \mathrm{C}$, which is in accordance with our observations, although we predicted a slightly higher maximum temperature for G. candidum growth in milk at the level of $36^{\circ} \mathrm{C}$. The optimal temperature for G. candidum growth is generally considered to be around $25^{\circ} \mathrm{C}[2,7]$. However, based on our results, the optimal temperature was predicted to be close to $30^{\circ} \mathrm{C}$. These data illustrate the variability in the optimal temperature for growth, which can at least be partially explained through the variability of strains and culture conditions, as also reported by Koňuchová and Valík [44].

Generally, within the experimental limits, the maximum specific growth rates of the isolate in milk with higher $a_{w}$ level $(0 \% \mathrm{NaCl})$ increased significantly $(p<0.05)$ with the increase in temperature up to an optimum, and then decreased beyond the physiological limits for the isolate. The graphical evaluation of the fitted curves in Figure 4 at temperatures below $21{ }^{\circ} \mathrm{C}$ indicates that when $a_{w}$ becomes more stressful (as a result of $1 \%$ $\mathrm{NaCl}$ addition), G. candidum exhibits a slightly faster growth rate compared to the growth predictions in milk without salt. A previous qualitative study by Hudecová et al. [52] showed a similar phenomenon. They investigated the effect of $\mathrm{NaCl}$ content on the radial growth of G. candidum and reported a similar trend, where kinetic growth over the entire temperature range (from 8 to $37^{\circ} \mathrm{C}$ ) was positively influenced by $1 \% \mathrm{NaCl}$ content in the growth medium. However, in Figure 4, it can also be noticed that, in the temperature interval from 25 to $34^{\circ} \mathrm{C}$, increased osmotic stress resulted in decreased growth potential, which was already indicated by the results of the primary modelling. In addition, both $T_{\max }$ and $\mu_{\mathrm{opt}}$ were lower for lower $a_{w}$ values.

The predicted growth kinetics of G. candidum J, which were influenced by temperature in Figure 4, demonstrated a similar growth response framework to that reported by Šípková et al. [50]. However, they observed slightly higher $\mu_{\text {opt }}$ values associated with the temperature of the G. candidum isolate A $\left(0.535 \pm 0.011 \mathrm{~h}^{-1}\right)$. Since they used the same experimental research design, the differences between the estimated $\mu_{\mathrm{opt}}$ of G. candidum may be related to the use of different isolates. This is in accordance with the polymorphism, as well as morphological and phenotypic variability, of G. candidum observed by some authors $[4,39]$. 


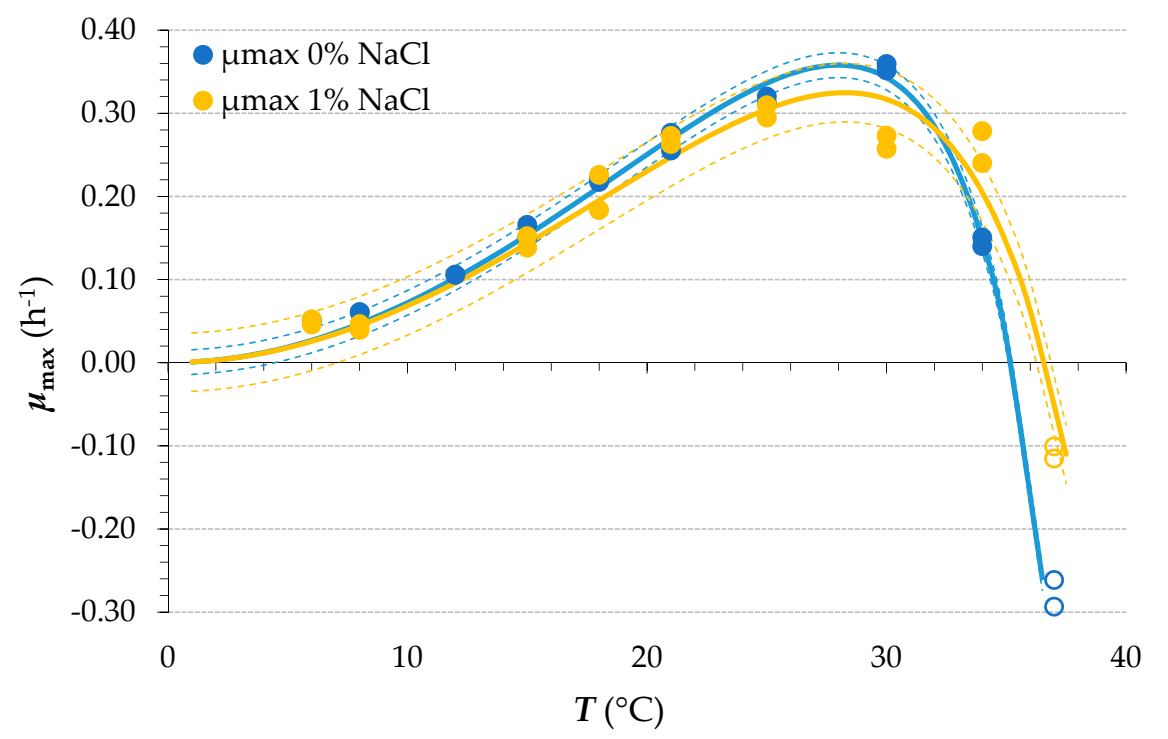

Figure 4. Plots of the maximum specific growth rate of $G$. candidum $\mathrm{J}$ versus temperature $\left(6-37^{\circ} \mathrm{C}\right.$ ) in milk (blue line) and milk with $1 \% \mathrm{NaCl}$ (yellow line) according to the $\mathrm{CM}$ (solid line). The symbols indicate the experimental $\mu_{\max }$ estimated from the primary growth curves at each incubation temperature. Solid lines represent the fitted model estimates. Dashed lines represent the $95 \%$ confidence intervals.

\subsection{Statistical Evaluation and Validation of Models}

The reliability of the predictive models used was assessed with the mathematical indices that are summarised in Table 3. Although the most common statistical index, $R^{2}$, was higher than 0.8 in all cases of the predictions in our study, this index is primarily adequate for linear models [53]. Therefore, the suitability of the primary predictive model used was also assessed with the RMSE index, which was higher in the case of G. candidum growth in milk with $1 \% \mathrm{NaCl}$ in comparison with the RMSE index of the model used in the predictions of the growth of the isolate in milk without salt. However, the values were still close to zero. The model is considered to be more suitable, as the RMSE value is closer to zero [54].

Table 3. Mathematical indices and validation factors of the models used, which describe the effects of temperature and $\mathrm{NaCl}$ presence on $\mathrm{G}$. candidum J growth in milk.

\begin{tabular}{|c|c|c|c|c|c|c|}
\hline & Model & $\% \mathrm{NaCl}$ & $R^{2}$ & RMSE & $A f$ & $B f$ \\
\hline \multirow{2}{*}{ Primary models } & \multirow{2}{*}{ BR } & 0 & $0.985-0.997$ & $0.092-0.027$ & - & - \\
\hline & & 1 & $0.966-0.999$ & $0.166-0.062$ & - & - \\
\hline \multirow{4}{*}{ Secondary models } & \multirow{2}{*}{$\mathrm{CM}_{1 / \lambda}$} & 0 & 0.983 & 0.127 & 1.116 & 1.007 \\
\hline & & 1 & 0.926 & 0.238 & 1.237 & 0.998 \\
\hline & \multirow{2}{*}{$\mathrm{CM}_{\mu}$} & 0 & 0.981 & 0.015 & 1.259 & 0.902 \\
\hline & & 1 & 0.888 & 0.035 & 1.296 & 0.909 \\
\hline
\end{tabular}

RMSE-root mean square error; $R^{2}$ —coefficient of determination; $A f$-accuracy factor; $B f$-bias factor; BRBaranyi and Roberts model; $\mathrm{CM}_{1 / \lambda}$-cardinal model applied to its lag phase data set; $\mathrm{CM}_{\mu}$-cardinal model applied to its growth rate.

A similar pattern of higher RMSE index values in the case of G. candidum growth in milk with $1 \% \mathrm{NaCl}$ was also demonstrated in the secondary modelling. The $\mathrm{CM}$ showed better performance for modelling of the lag phase than for the growth rate based on the RMSE indices, and the values were in the range of or lower than the values of the RMSE reported by Garcia et al. [55], who applied extended Davey and general polynomial models to study fungal radial growth. Satisfactory predictions of fungal growth in relation to temperature with the use of the CM were also reported by other authors [56,57]. 
Ideally, predictive models would have $A_{f}=B_{f}=1$. However, $A_{f}$ can increase by $10-15 \%$ for every variable in the model [58]. Therefore, if the model predicts the effect of the temperature (as the only factor) on the microbial growth, the best expected $A_{f}$ would be 1.1-1.2 [58,59]. In our study, the $A_{f}$ factors were slightly higher than 1.2. The satisfactory $B_{f}$ factor limits were related to the specific application of the model. If $B_{f}<1$, then the model overpredicts the observed growth rate and, thus, the model is considered to be "fail-safe" in terms of the growth rate predictions for spoilage or pathogenic microorganisms [58]. However, an acceptable interval of the $B_{f}$ factor for predictive models is 0.75-1.25 [34]. All $B_{f}$ factors calculated in our study were in the acceptable interval.

\section{Conclusions}

The present study provides quantitative growth data on the behaviour of a dairy isolate in milk under a wide range of temperature conditions. The effect of $1 \% \mathrm{NaCl}$ on the growth kinetics of the studied microscopic fungus was also expressed quantitatively. The outputs of the G. candidum growth modelling can be used for several types of prediction in dairy practice. Firstly, it may assist in predicting conditions under which the growth of G. candidum is unfavourable from the point of view of food spoilage. Based on the presented data, the food technologists may also estimate the time that is required for G. candidum growth to reach the hygienic relevant limit. It may also be considered in the effort to extend the shelf life of raw milk dairy products or to adequately define their "use by" date. On the other hand, the results can be applied as a tool to evaluate the temperature conditions for achieving a specific growth rate, e.g., in an artisanal cheese making process, according to the operational parameters.

Author Contributions: Conceptualization, M.K. and A.M.; methodology, M.K., A.M., and L.V.; validation, M.K. and L'.V.; formal analysis, P.Š., M.K., A.M., and L'.V.; investigation, P.Š., M.K., and M.T.; writing—original draft preparation, P.Š. and M.K.; writing—review and editing, A.M. and L'.V.; visualization, M.K. and L'.V.; supervision, A.M. and L'.V.; funding acquisition, L'.V. All authors have read and agreed to the published version of the manuscript.

Funding: This research was funded by the Slovak Research and Development Agency, grant number APVV-19-0031, and the Scientific Grant Agency of the Ministry of Education, Science, Research, and Sports of the Slovak Republic and Slovak Academy of Sciences, grant number VEGA 1/0532/18.

Institutional Review Board Statement: Not applicable.

Informed Consent Statement: Not applicable.

Data Availability Statement: The data presented in this study are available upon reasonable request from the corresponding author.

Conflicts of Interest: The authors declare no conflict of interest.

\section{References}

1. Wouters, J.T.M.; Ayad, E.H.E.; Hugenholtz, J.; Smit, G. Microbes from raw milk for fermented dairy products. Int. Dairy J. 2002, 12, 91-109. [CrossRef]

2. Boutrou, R.; Guéguen, M. Interests in Geotrichum candidum for cheese technology. Int. J. Food Microbiol. 2005, 102, 1-20. [CrossRef]

3. Pottier, I.; Gente, S.; Vernoux, J.P.; Guéguen, M. Safety assessment of dairy microorganisms: Geotrichum candidum. Int. J. Food Microbiol. 2008, 126, 327-332. [CrossRef] [PubMed]

4. Marcellino, N.; Benson, D.R. The good, the bad, and the ugly: Tales of mold-ripened cheese. Microbiol. Spectr. 2013, 1, 1-27.

5. Koňuchová, M.; Liptáková, D.; Šípková, A.; Valík, L'. Role of Geotrichum candidum in Dairy Industry. Chem. Pap. 2016, 110, 491-497.

6. Gente, S.; Sohier, D.; Coton, E.; Duhamel, C.; Guéguen, M. Identification of Geotrichum candidum at the species and strain level: Proposal for a standardized protocol. J. Ind. Microbiol. Biotechnol. 2006, 33, 1019-1031. [CrossRef]

7. Eliskases-Lechner, F.; Guéguen, M.; Panoff, J.M. Geotrichum candidum. In Encyclopedia of Dairy Sciences, 2nd ed.; Fuquay, J.W., Fox, P.F., McSweeney, P.L.H., Eds.; Academic Press: London, UK, 2011; pp. 765-771.

8. Bourdichon, F.; Casaregola, S.; Farrokh, C.; Frisvad, J.C.; Gerds, M.L.; Hammes, W.P.; Harnett, J.; Huys, G.; Laulund, S.; Ouwehand, A.; et al. Food fermentations: Microorganisms with technological beneficial use. Int. J. Food Microbiol. 2012, 154, 87-97. [CrossRef] [PubMed] 
9. Alexandraki, V.; Kazou, M.; Angelopoulou, A.; Arena, M.P.; Capozzi, V.; Russo, P.; Fiocco, D.; Spano, G.; Papadimitriou, K.; Tsakalidou, E. The microbiota of non-cow milk and products. In Non-Bovine Milk and Milk Products; Tsakalidou, E., Papadimitriou, K., Eds.; Academic Press: London, UK, 2011; pp. 117-159.

10. Garnier, L.; Valence, F.; Mounier, J. Diversity and control of spoilage fungi in dairy products: An update. Microorganisms 2017, 5, 42. [CrossRef]

11. Wszolek, M.; Kupiec-Teahan, B.; Guldager, H.S.; Tamime, A.Y. Production of kefir, koumiss and other related products. In Fermentd Milks; Tamime, A., Ed.; Blackwell Science Ltd.: Oxford, UK, 2006; pp. 174-216.

12. Šipošová, P.; Koňuchová, M.; Valík, L'.; Medved'ová, A. Growth dynamics of lactic acid bacteria and dairy microscopic fungus Geotrichum candidum during their co-cultivation in milk. Food Sci. Technol. Int. 2020, in press. [CrossRef]

13. Šipošová, P.; Lehotová, V.; Valík, L'; Medved'ová, A. Microbiological quality assessment of raw milk from a vending machine and of traditional Slovakian pasta filata cheeses. J. Food Nutr. Res. 2020, 59, 272-279.

14. Kazou, M.; Grafakou, A.; Tsakalidou, E.; Georgalaki, M. Zooming into the microbiota of home-made and industrial kefir produced in Greece using classical microbiological and amplicon-based metagenomics analyses. Front. Microbiol. 2021, 12, 64. [CrossRef] [PubMed]

15. Jaster, H.; Judacewski, P.; Ribeiro, J.C.B.; Zielinski, A.A.F.; Demiate, I.M.; Los, P.R.; Alberti, A.; Nogueira, A. Quality assessment of the manufacture of new ripened soft cheese by Geotrichum candidum: Physicochemical and technological properties. Food Sci. Technol. 2019, 39, 50-58. [CrossRef]

16. Fröhlich-Wyder, M.T.; Arias-Roth, E.; Jakob, E. Cheese yeasts. Yeast 2018, 36, 129-141. [CrossRef]

17. Naz, S.; Cretenet, P.; Vernoux, J.P. Current knowledge on antimicrobial metabolites produced from aromatic amino acid metabolism in fermented products. In Microbial Pathogens and Strategies for Combating Them: Science, Technology and Education; Méndez-Vilas, A., Ed.; Formatex Research Center: Badajoz, Spain, 2013; pp. 337-346.

18. Naz, S.; Gueguen-Minerbe, M.; Cretenet, M.; Vernoux, J.P. Aromatic amino acids as precursors of antimicrobial metabolites in Geotrichum candidum. FEMS Microbiol. Lett. 2013, 344, 39-47. [CrossRef] [PubMed]

19. Featherstone, S. Cleaning and sanitizing. In A Complete Course in Canning and Related Processes; Featherstone, S., Ed.; Woodhead Publishing: Sawston, Cambridge, UK, 2015; Volume 1, pp. 149-171.

20. Adour, L.; Couriol, C.; Amrane, A. Differentiation between amino acids used as carbon and energy sources during growth of Geotrichum candidum Geo17. Food Technol. Biotechnol. 2005, 43, 85-89.

21. Adour, L.; Bude, F.; Amrane, A. Sequential use of ammonium and leucine as nitrogen sources during growth of Geotrichum candidum on a glucose based medium. Electron. J. Biotechnol. 2010, 13, 13-14.

22. Boutrou, R.; Kerriou, L.; Gassi, J.-Y. Contribution of Geotrichum candidum to the proteolysis of soft cheese. Int. Dairy J. 2006, 16, 775-783. [CrossRef]

23. Swinnen, I.A.; Bernaerts, K.; Dens, E.J.; Geeraerd, A.H.; Van Impe, J.F. Predictive modelling of the microbial lag phase: A review. Int. J. Food Microbiol. 2004, 94, 137-159. [CrossRef]

24. Valdramidis, V. Predictive microbiology. In Modeling in Food Microbiology: From Predictive Microbiology to Exposure Assessment, 1st ed.; Membré, J.-M., Valdramidis, V., Eds.; ISTE Press-Elsevier: London, UK, 2016; pp. 1-15.

25. Ross, T.; McMeekin, T.A. Predictive microbiology. Int. J. Food Microbiol. 1994, 23, 241-264. [CrossRef]

26. Samson, R.A.; Hoekstra, E.S.; Frisvad, J.S.; Filtenborg, O. Introduction to Food-and Airborne Fungi, 6th ed.; Centraalbureau voor Schimmelcultures: Utrecht, The Netherlands, 2002; pp. 28-389.

27. De Hoog, G.S.; Smith, M.T. Galactomyces Redhead \& Malloch (1977). In The Yeasts, a Taxonomic Study, 5th ed.; Kurtzman, C.P., Fell, J.W., Boekhout, T., Eds.; Elsevier: Amsterdam, The Netherlands, 2011; Volume 2, pp. 413-420.

28. Groenewald, M.; Coutinho, T.; Smith, M.T.; van der Walt, J.P. Species reassignment of Geotrichum bryndzae, Geotrichum phurueaensis, Geotrichum silvicola, and Geotrichum vulgarae based on phylogenetic analyses and mating compability. Int. J. Syst. Evol. Microbiol. 2012, 62, 3072-3080. [CrossRef]

29. ISO 21527-1:2010. Microbiology of Food and Animal Feeding Stuffs-Horizontal Method for the Enumeration of Yeasts and Moulds—Part 1: Colony Count Technique in Products with Water Activity Greater than 0.95; ICS 07.100.30; ISO: Geneva, Switzerland, $2010 ;$ pp. 1-12.

30. Baranyi, J.; Roberts, T.A. A dynamic approach to predicting bacterial growth in food. Int. J. Food Microbiol. 1994, 23, 277-294. [CrossRef]

31. Rosso, L.; Lobry, J.R.; Flandrois, J.P. An unexpected correlation between cardinal temperatures of microbial growth highlighted by a new model. J. Theor. Biol. 1993, 162, 447-463. [CrossRef] [PubMed]

32. Ratkowsky, D. Model fitting and uncertainty. In Modeling Microbial Responses in Food, 1st ed.; McKellar, R.C., Yu., X., Eds.; CRC Press Inc.: Boca Raton, FL, USA, 2004; pp. 151-196.

33. TeGiffel, M.C.; Zwietering, M.H. Validation of predictive models describing the growth of L. monocytogenes. Int. J. Food Microbiol. 1999, 46, 135-149. [CrossRef]

34. Ačai, P.; Valík, L'. Predictive Food Microbiology and Risk Assessment, Examples and Tasks, 1st ed.; SPEKTRUM STU: Bratislava, Slovakia, 2020; pp. 18-186.

35. Baranyi, J.; Pin, C.; Ross, T. Validating and comparing predictive models. Int. J. Food Microbiol. 1999, 48, 159-166. [CrossRef]

36. Gougouli, M.; Koutsoumanis, K.P. Primary models for fungal growth. In Predictive Mycology, 1st ed.; Dantigny, P., Panagou, E.Z., Eds.; Nova Science Publishers: New York, NY, USA, 2013; pp. 63-130. 
37. Garcia, D.; Ramos, A.J.; Sanchis, V.; Marín, S. Predicting mycotoxins in foods: A review. Food Microbiol. 2009, 26, 757-769. [CrossRef] [PubMed]

38. Halmi, M.I.E.; Shukor, M.S.; Shukor, M.Y. Evaluation of several mathematical models for fitting the growth and kinetics of the catechol-degrading Candida parapsilopsis: Part 1. J. Environ. Bioremediation Toxicol. 2014, 2, 48-52.

39. Koňuchová, M.; Valík, L'. Evaluation of radial growth dynamics variability of Geotrichum candidum: A quantitative approach. J. Food Nutr. Res. 2017, 56, 155-166.

40. López, S.; Prieto, M.; Dijkstra, J.; Dhanoa, M.S.; France, J. Statistical evaluation of mathematical models for microbial growth. Int. J. Food Microbiol. 2004, 96, 289-300. [CrossRef] [PubMed]

41. Bertrand, R.L. Lag phase is a dynamic, organized, adaptive, and evolvable period that prepares bacteria for cell division. J. Bacteriol. 2019, 201, 1-21. [CrossRef] [PubMed]

42. Görner, F.; Valík, L'. Applied Microbiology of Foods, 1st ed.; Malé centrum: Bratislava, Slovakia, 2004; pp. $271-338$.

43. Fox, P.F.; Uniacke-Lowe, T.; McSweeney, P.L.H.; O'Mahony, J.A. Dairy Chemistry and Biochemistry, 2nd ed.; Springer International Publishing: Cham, Switzerland, 2015; pp. 499-546.

44. Koňuchová, M.; Valík, L'. Modelling the radial growth of Geotrichum candidum: Effects of temperature and water activity. Microorganisms 2021, 9, 532. [CrossRef]

45. Cornelison, C.; Crow, S.A. Yarrowia lipolytica (Candida lipolytica). In Encyclopedia of Food Microbiology, 2nd ed.; Batt, C.A., Tortello, M.-R., Eds.; Academic Press: Cambridge, UK, 2014; pp. 374-378.

46. Wrent, P.; Rivas, E.M.; Gil de Prado, E.; Peinado, J.M.; de Silóniz, M.I. Debaryomyces. In Encyclopedia of Food Microbiology, 2nd ed.; Batt, C.A., Tortello, M.-R., Eds.; Academic Press: Cambridge, UK, 2014; pp. 563-570.

47. Agarbati, A.; Canonico, L.; Marini, E.; Zannini, E.; Ciani, M.; Comitini, F. Potential probiotic yeasts sourced from natural environmental and spontaneous processed foods. Foods 2020, 9, 287. [CrossRef]

48. Pichereau, V.; Hartke, A.; Auffray, A. Starvation and osmotic stress induced multiresistances influence of extracellular compounds. Int. J. Food Microbiol. 2000, 55, 19-25. [CrossRef]

49. Hudecová, A.; Valík, L'.; Liptáková, D. Influence of temperature on the surface growth of Geotrichum candidum. Acta Chim. Slovaca. 2009, 2, 75-87.

50. Šípková, A.; Valík, L.; Čižniar, M.; Liptáková, D. Characterization of mutual relations between Geotrichum candidum and Lactobacillus rhamnosus GG in milk: A quantitative approach. Food Sci. Technol. Int. 2014, 20, 23-31. [CrossRef]

51. Uraz, T.; Özer, B.H. Molds Employed in Food Processing. In Encyclopedia of Food Microbiology, 2nd ed.; Batt, C.A., Tortello, M.-R., Eds.; Academic Press: Cambridge, UK, 2014; pp. 522-528.

52. Hudecová, A.; Valík, L'.; Liptáková, D. Surface growth of Geotrichum candidum: Effect of the environmental factors on its dynamics. Slovak J. Food Sci. 2011, 5, 17-22. [CrossRef]

53. Pérez-Rodríguez, F.; Valero, A. Predictive Microbiology in Foods, 5th ed.; Springer Science+Business Media: New York, NY, USA, 2013; pp. 25-55.

54. Choi, W.S.; Son, N.; Cho, J.I.; Joo, I.S.; Han, J.A.; Kwak, H.S.; Hong, J.H.; Suh, S.H. Predictive model of Staphylococcus aureus growth on egg products. Food Sci. Biotechnol. 2019, 28, 913-922. [CrossRef]

55. Garcia, D.; Ramos, A.J.; Sanchis, V.; Marín, S. Modelling the effect of temperature and water activity in the growth boundaries of Aspergillus ochraceus and Aspergillus parasiticus. Food Microbiol. 2011, 28, 406-417. [CrossRef]

56. Gougouli, M.; Koutsoumanis, K.P. Modelling growth of Penicillium expansum and Aspergillus niger at constant and fluctuating temperature conditions. Int. J. Food Microbiol. 2010, 140, 254-262. [CrossRef]

57. Romero-Gil, V.; Bautista-Gallego, J.; Rodríguez-Gómez, F.; García-García, P.; Jiménez-Díaz, R.; Garrido-Fernández, A.; ArroyoLópez, F.N. Evaluating the individual effects of temperature and salt on table olive related microorganisms. Food Microbiol. 2013, 33, 178-184. [CrossRef]

58. Ross, T.; Dalgaard, P.; Tienungoon, S. Predictive modelling of the growth and survival of Listeria in fishery products. Int. J. Food Microbiol. 2000, 62, 231-245. [CrossRef]

59. Medved'ová, A.; Šipošová, P.; Mančušková, T.; Valík, L'. The effect of salt and temperature on the growth of Fresco culture. Fermentation 2019, 5, 2. [CrossRef] 